\title{
Os Sete helenistas e os dispersos de Jerusalém: o serviço às mesas como diaconia de encontro e construção identitária da missão na igreja apostólica
}

\author{
The Seven Hellenists and the dispersed from \\ Jerusalem: \\ the table service as diakonia of encounter and \\ construction of identity of the mission in the apostolic \\ church
}

Luciano Rocha Pinto

\section{Resumo}

O "serviçoàs mesas", como dimensão caritativa, tem sido tradicionalmente pensado como razão de ser do ministério diaconal. Seu serviço, no entanto, não está isolado nas obras de assistência. $\mathrm{O}$ anúncio do Evangelho, a pregação e a catequese são elementos próprios do ministério diaconal. Neste sentido, este trabalho tem por objetivo refletir sobre o munus docendi confiado ao diácono, tomando como estudo de caso a missão dos Sete helenistas e de seus epígonos, pontuando sua importância no processo de expansão do cristianismo a partir da formulação de uma nova mentalidade missionária. Coube aos Sete uma missão caracteristicamente urbana, que moveu o cristianismo da palestina para o mundo greco-romano. Sua missão entre os helenistas e os gentios foi a ponte entre o Evangelho de Jesus e a teologia de Paulo. Desde muito 
cedo, abandonaram os traços e os rituais meramente judaicos e passaram a admitir novos membros a partir de novos critérios, mais afinados ao ambiente gentílico.

Palavras-chave: Igreja apostólica. Ministério diaconal. Missão.

\begin{abstract}
"Table service", as a charitable dimension, has traditionally been thought of as the raison d'être of the diaconal ministry. His service, however, is not isolated in the assistance work. The proclamation of the Gospel, preaching and catechesis are elements specific of the diaconal ministry. In this sense, this work aims to reflect on the munus docendi entrusted to the deacon, taking as a case study the mission of the Seven Hellenists and their epigones, highlighting its importance in the process of expansion of Christianity from the formulation of a new missionary mentality. The Seven had a characteristically urban mission, which moved Christianity from Palestine to the Greco-Roman world. His mission between the Hellenists and the Gentiles was the bridge between the Gospel of Jesus and the theology of Paul. From an early age, they abandoned their Jewish traits and rituals and began to admit new members based on new criteria, more attuned to the Gentile environment.
\end{abstract}

Keywords: Apostolic Church. Diaconal ministry. Mission.

\title{
Introdução
}

A instituição do diaconado tem sua origem tradicional em Atos dos Apóstolos, capítulo 6. O estabelecimento do ministério dos Sete "servidores" - diáconos - vem ao encontro de uma primeira organização eclesial a serviço

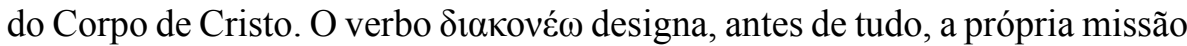
de Cristo como servidor (Mt 10,45; Mt 12,18; At 4,30; Fl 2,6-11). Designa também o exercício do serviço pelos seus discípulos (Mc 10,43-45; Mt 20,26$28 ; 23,11 ; \mathrm{Lc} 8,3 ; \mathrm{Rm} 15,25)$, mas, também o serviço apostólico de pregar o Evangelho. A tarefa de ensinar está na base da missão da Igreja: "ide e ensinai a todos os povos..." (Mt 28,19). $\Delta$ takové $\omega$, ou seja, a noção de serviço e de estar a serviço, é a característica essencial do ministério do apóstolo. 
"Diaconado" e "apostolado" são por vezes tratados como sinônimos. Por ocasião da associação de Matias ao grupo dos Doze, Pedro associa apostolado e diaconia. ${ }^{1}$ Há, contudo, poucos trabalhos dedicados à atuação dos Sete e, principalmente, da sua importância na expansão do Evangelho.

Este trabalho tem por objetivo refletir sobre o munus docendi confiado ao diácono, tomando como estudo de caso a missão dos Sete e seus epígonos, a fim de demonstrar sua importância no processo de expansão do cristianismo e da formulação de uma nova mentalidade missionária. Alguns dos paradigmas cristãos fundamentais, que iriam influenciar o cristianismo em sua mensagem universal, são frutos da reflexão teológica que os Sete e seus discípulos desenvolveram e aplicaram. Estes representam uma ponte entre os ensinamentos de Jesus e a teologia que, mais tarde, Paulo sofisticará. ${ }^{2}$

$\mathrm{O}$ trabalho está dividido em três partes. Na primeira, Os helenistas e os Sete, apresento o ambiente de expansão do cristianismo e analiso como a cultura helenista, em contato com o Evangelho, foi fundamental para produzir uma mentalidade aberta e inclusiva, que forjará os contornos da missão universal da Igreja. Na segunda parte, A emergência de uma nova mentalidade missionária, procuro analisar a missão dos Sete e de seus epígonos, demonstrando que foi graças a eles que o cristianismo adquiriu contornos próprios e desenvolveu-se livremente das leis judaicas. São, pois, os iniciadores da missão para fora de Jerusalém. Por fim, em A diaconia dos Sete como comunhão de mesa e missão eclesial, procuro elucidar como a ação dos helenistas dispersos de Jerusalém abre caminho para uma nova práxis missionária. A diaconia aplicada por eles foi progressivamente se estabelecendo e se afirmando como missão eclesial.

O munus docendi, ou seja, o anúncio do Evangelho, a pregação e a catequese são elementos próprios do ministério diaconal. ${ }^{3} \mathrm{O}$ "serviço às mesas", razão de sua emergência, será abordado no contexto de sua atuação e, portanto, visto de maneira diversa da dominante que parece absolutizar sua atuação no campo do amparo social. Santo Inácio de Antioquia, inclusive, parece recusar ver na função diaconal uma apropriação das obras assistenciais: "pois não é de comidas e bebidas que são diáconos, mas são servos da Igreja de Deus". ${ }^{4}$ São, portanto, ministros da Igreja, ${ }^{5}$ a quem foi confiado o serviço

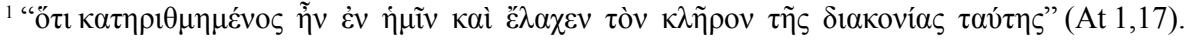

${ }^{2}$ HENGEL, M., The Origins of the Christian Mission, p. 48-64.

${ }^{3}$ BENDINELLI, J. C., Diaconia da Palavra, p. 71.

${ }^{4}$ INÁCIO DE ANTIOQUIA, Epístola aos Tralianos, 2,3.

${ }^{5}$ INÁCIO DE ANTIOQUIA, Epístola aos Tralianos, 2,3.
} 
de Jesus Cristo. ${ }^{6}$ Seus apontamentos são pistas inquietantes de sua atuação na época apostólica que passamos, então, a analisar.

\section{Os helenistas e os Sete}

A mensagem cristã, desde o começo de sua difusão, confrontou-se com três ambientes diferentes: o judaico palestinense, o judaico helenista e o gentílico. Do primeiro grupo emergiu o cristianismo. Falavam hebraico e viviam o ensinamento de Jesus de maneira rígida ao mesmo tempo que conservavam a tradição patriarcal. Inicialmente, contava um pequeno grupo que Jesus deixou em Jerusalém após sua ascensão. Acreditavam viver um judaísmo mais puro que aquele vivido por seus pais. ${ }^{7}$ Não por acaso, continuavam a orar regularmente no templo (At 2, 46; 3,1-3). Eram tolerados pelas autoridades religiosas judaicas, ao menos até o ano 44 quando sofreram perseguição por Herodes Agripa. Os gentios não eram vistos, inicialmente, como destinatários de sua mensagem. Sua entrada no cristianismo deveu-se aos helenistas.

Os Helenistas ou judeus da diáspora moravam nas cidades do mundo persa e grecorromano. Eram descendentes dos que foram levados cativos pelos assírios e babilônios e que não retornaram a Israel com a autorização no século VI a.C. A vida destes judeus na Babilônia era relativamente tranquila. Trabalhavam como comerciantes e administradores, com negócios diversos pela Ásia. Muitos foram morar no Egito. Não poucos deixaram de falar o hebraico, assumindo o grego paulatinamente como língua hodierna e nativa. Com o advento de Alexandre Magno (336 - 323 a.C.) e das dinastias helenistas dos Selêucidas (323 - 64 a.C.) e dos Ptolomeus (que governaram o Egito de 305 a 30 a.C.), a dispersão dos judeus estendeu-se do Egito à Síria. Desde muito cedo ocorreram trocas culturais. No Egito, o filósofo judeu Fílon de Alexandria (20 a.C. - c.50 d.C.), aproximou o pensamento judaico da filosofia grega. Na Síria, de modo especial em Antioquia, encontrava-se uma pujante comunidade judaica naquela que era a terceira maior cidade do Império Romano. O judaísmo não apenas era tolerado, mas, tinha suas próprias leis religiosas respeitadas. No século I d.C. muitos obtiveram cidadania romana. Saulo, de Tarso, foi um judeu helenista que gozava desse benefício. ${ }^{8}$

Esses judeus eram cosmopolitas e viviam um judaísmo menos rígido que

${ }^{6}$ INÁCIO DE ANTIOQUIA, Epístola aos Magnésios, 6,1.

${ }^{7}$ PIERRARD, P., História da Igreja, p. 18.

${ }^{8}$ IRVIN, D. T.; SUNQUIST, S. W., História do movimento cristão mundial, p. 34-38. 
o praticado em Jerusalém. O centro do culto judaico, o Templo, se relativizou pela distância. A vida cultual desses helenistas ocorria na sinagoga. Ali a comunidade judaica da cidade se encontrava numa vivência religiosa mais centrada na palavra, com o estudo da Torá e com a recitação dos Salmos. Um levantamento realizado por Louis Feldman contabiliza sessenta e seis sinagogas geograficamente espalhadas entre a região do Mar Negro e Egito costeando o Mediterrâneo até a Espanha. ${ }^{9}$ Essa instituição baseavase no princípio da participação pública. Seu culto estava aberto a todos que desejassem participar, de forma que muitos gentios foram se sentindo atraídos pelo monoteísmo. Alguns se convertiam, os chamados "prosélitos". Outros, frequentavam as sinagogas, mas, não se deixavam circuncidar, os denominados "tementes a Deus".

Em Jerusalém também havia sinagogas de judeus da diáspora. Sua existência, ladeando o Templo, aponta para uma tendência do judaísmo antigo não completamente satisfeito com os sacrifícios cultuais. ${ }^{10}$ As sinagogas praticavam um culto incruento e entendido como evento da Palavra, onde as orações e as esmolas eram consideradas sacrifícios superiores. ${ }^{11}$ A língua e a cultura, por si mesmas, pareciam construir identidades litúrgicas distintas, visível no uso das Escrituras Sagradas. Os helenistas utilizavam a tradução das escrituras do hebraico para o grego conhecida por Septuaginta (palavra grega que significa Setenta). ${ }^{12}$

Os círculos sinagogais helenistas, por gerações, cultivaram a língua grega e estabeleceram uma cultura de proximidade e de troca com outras

\footnotetext{
${ }^{9}$ FELDMAN, L., Diaspora Synagogues, p. 577-602.

${ }^{10}$ BARRETT, C. K., The International Critical Commentary.

${ }^{11}$ EBNER, M., Dos primórdios até a metade do século II, p. 15-16.

${ }^{12}$ A carta de Aristéia a Filocrates, obra helenística do século III a.C., narra de forma lendária, como nasceu essa tradução. Teria, então, o rei egípcio Ptolomeu II (285-245 a.C.) encomendado às autoridades religiosas de Jerusalém uma tradução em grego do Pentateuco para a biblioteca de Alexandria. O sumo sacerdote Eleazário nomeou setenta e dois eruditos judeus que foram até o Egito e na Ilha de Faro realizaram a tradução em setenta e dois dias, cada um fazendo a própria tradução dos cinco primeiros livros da Bíblia. No final dos trabalhos se reuniram e, comparando o trabalho feito, viram que todas as traduções eram idênticas. Historicamente, os tradutores eram em número de cinco e setenta eram os membros do tribunal (sinédrio) que aprovaram a tradução feita. Sem dúvida, é uma tradução feita no Egito e tida, pelas autoridades de Jerusalém, como uma boa versão, texto próprio para o uso litúrgico nas sinagogas. A Septuaginta logo se tornou, desde cedo, sinal de uma transformação religiosa mais ampla que ocorria no judaísmo helenista (IRVIN, D. T.; SUNQUIST, S. W., História do movimento cristão mundial, p 36).
} 
etnias e nações. Viviam um judaísmo mais tolerante para com as diferenças. Eram capazes de aceitar simpatizantes do monoteísmo judaico (caso dos "tementes a Deus") que não estavam dispostos a se submeter à circuncisão e, a um só tempo, estavam abertos a incluir plenamente os gentios dispostos a se circuncidar e adotar o judaísmo como expressão de fé (caso dos "prosélitos"). Muitos, fixando residência em Jerusalém, continuariam a ler e a estudar as escrituras judaicas em sua língua materna: o grego. Assim viviam um judaísmo menos dependente do Templo, ainda que não totalmente distante. Essa divisão parece reproduzir-se dentre aqueles que aceitaram a mensagem de Jesus como o Messias esperado.

Lucas, no seu Atos dos Apóstolos, conta que "aumentando o número dos discípulos, surgiram murmurações dos helenistas contra os hebreus" (At 6,1). As diferenças entre os primeiros convertidos ao Evangelho foram reduzidas e minimizadas pelo autor. Reclamavam, pois, "suas viúvas estavam sendo esquecidas na distribuição diária” (At 6,1). Lucas, helenista de Antioquia, introduz em Atos 6 um assunto completamente novo: a conversão de judeus helenistas, a instituição de um núcleo de governo distinto dos Doze (de tradição e de língua grega) e sua ação missionária cujo termo é a fundação da Igreja de Antioquia e a aplicação de uma nova mentalidade missionária. O grupo dos Sete, tradicionalmente identificado como os primeiros diáconos, será responsável por empreender as mais decisivas mudanças na caminhada ulterior do cristianismo. ${ }^{13}$

Hengel afirma que "a separação de dois grupos em Jerusalém havia se tornado necessária em razão da linguagem da sua liturgia". ${ }^{14}$ Assim, os Sete seriam os líderes dos convertidos de língua grega, os helenistas. A noção de "linguagem da sua liturgia", utilizada por Hengel, parece dizer respeito ao

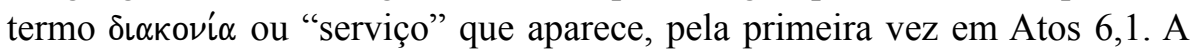
palavra "liturgia" tem origem no grego leitourgos e designa "obra pública" ou "serviço em prol do outro ou para o outro". ${ }^{15}$ No Novo Testamento, a palavra "liturgia" é empregada para designar, não somente a celebração do culto divino mas também o anúncio do Evangelho (Rm 15,16; F1 2,14-17.30) e a caridade fraterna (Rm 15,27; 2Cor 9,12; F1 2,25). Cabia, portanto, aos Sete, o

\footnotetext{
${ }^{13}$ EBNER, M., Dos primórdios até a metade do século II, p. 12.

${ }^{14}$ HENGEL, M., The Origins of the Christian Mission, p. 55.

${ }^{15}$ Originariamente, a palavra "liturgia" significa "obra pública", "serviço por parte dele em favor do povo". Na tradição cristã, quer dizer que o povo de Deus toma parte na "obra de Deus" (CEC 1069).
} 
serviço à mesa dos helenistas e de suas viúvas. Lucas segue mostrando que seu serviço, sua diaconia, não se reduz à assistência, mas, deve ser compreendida à semelhança da missão apostólica, pois, pregam, fazem milagres, convertem, doam a própria vida pelo Evangelho. Diaconia e liturgia estão atravessadas na vida e na missão dos Sete. Sua proximidade da missão apostólica pode

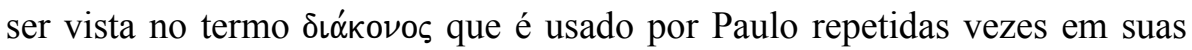
epístolas e designa, naquele contexto, a função do pregador, do ministro da Palavra e do missionário. Paulo aproxima os conceitos de apóstolo e de diácono quando faz referência à sua missão: "Paulo, diácono de Cristo Jesus, chamado para ser apóstolo, escolhido para o Evangelho de Deus... E a vós gentios, eu digo: enquanto apóstolo dos gentios, eu honro o meu ministério (diaconia)" (Rm 1,1; 11,13). Segundo Paulo, é Deus que o tornou "diácono

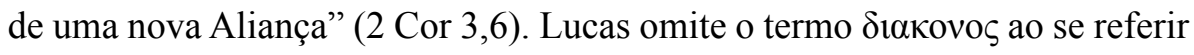

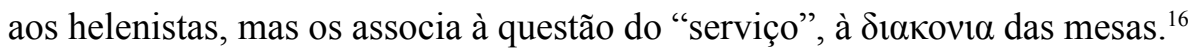

Lucas narra que os Doze reuniram os discípulos e lhes propuseram escolher sete homens dentre os helenistas. Estes precisavam ser dignos: homens de boa reputação, repletos do Espírito e de sabedoria (At 6, 2-3). A narrativa aponta para a valorização missionária dos primeiros diáconos, aproximando os Sete dos Doze e colocando-os em relação simbólica com a história de Israel. Sete é o número de nações pagãs que habitavam Canaã antes da chegada dos hebreus. Doze corresponde ao número das tribos de Israel. Os Sete "helenistas" representam as nações que habitavam a terra prometida por Iahweh aos hebreus, da mesma forma que o número dos apóstolos de Jesus remonta, em termos simbólicos, às doze tribos de Israel. ${ }^{17} \mathrm{~A}$ identificação dos Sete com as nações pagãs aponta diretamente para seu campo de atuação. Lucas, ao escrever o livro de Atos, considera a atuação do grupo dos diáconos e de seus discípulos no contexto de expansão do cristianismo, sendo os primeiros a integrar gentios na fé cristã (At 8,12-13.27-38; 11,1.18.20-21).

Escolhidos os sete helenistas, os Apóstolos oraram e impuseram as mãos (At 6,6), sinais tradicionais que conferem ao ofício o caráter sacramental, gesto que os liga à missão dos Doze e ao serviço investido com a autoridade de Cristo. ${ }^{18}$ A partir de então Lucas ocupa-se de narrar a missão dos helenistas, de modo especial, de Estêvão e Filipe. Uma nova mentalidade missionária nascerá do encargo apostólico de servir as mesas.

\footnotetext{
${ }^{16}$ SELVATICI, M., Os judeus helenistas e a primeira expansão cristã, p. 193.

${ }^{17}$ SELVATICI, M., Os judeus helenistas e a primeira expansão cristã, p. 195.

${ }^{18}$ AQUINO, J. P. T., Atos 6.1-7, p. 9-20.
} 


\section{A emergência de uma nova mentalidade missionária}

A diferença entre palestinenses e helenistas não está circunscrita à discordância que emergiu por causa das viúvas. Ela é "fruto certamente, de seus diferentes modos de ver a vida e a fé". ${ }^{19}$ Um olhar atento a atuação dos Sete dará visibilidade àquele modo de ser e de viver a fé. A trajetória dos cristãos helenistas pode ser vista no livro dos Atos dos Apóstolos $(6,1-8,40$; 11,19-26). As condições histórico-culturais dos cristãos helenistas associadas à mensagem evangélica colocarão em movimento uma mentalidade missionária nova, com novos contornos e outros destinatários da Boa Nova de Jesus Cristo. Lucas, em sua narrativa, faz emergir este novo modo de ser a partir da missão de Filipe e de Estêvão que, originariamente, seguem o modelo em vigor: dirigir-se aos judeus. Assim ocorre! Estêvão vai aos helenistas de Jerusalém. $\mathrm{Na}$ Sinagoga dos libertos ocorre uma controvérsia que será o estopim para a implementação da nova mentalidade missionária de caráter universalista. Alguns se levantaram contra ele e subornaram falsas testemunhas dizendo que ele blasfemara contra Moisés, contra o Templo e contra Deus. Amotinaram o povo, os anciãos, os escribas e levaram-no preso ao Grande Conselho (At 6, 8-12).

No capítulo 7 de Atos encontramos o mais extenso e elaborado discurso do livro. Trata-se de um sermão contra o endurecimento dos corações daqueles que não reconhecem em Jesus, o Messias esperado. O discurso de Estêvão é uma releitura da história de Israel. Sua retrospectiva fixa a atenção de seus interlocutores em Abraão, José e Moisés (At 7,2-43). Destaca que a história de Israel sempre foi dirigida por Deus e cabe, portanto, ao povo escolhido prestar culto, honrar e louvar ao Senhor. Contudo, a história da salvação é uma história de recusa constante dos líderes que Deus levantou para guiar o povo (At 7, 2-47). Conforme Casalegno:

Sem prejudicar a vocação cultual do povo bíblico, Lucas não absolutiza o lugar sagrado do Templo de Jerusalém. Mostra sua provisoriedade, destacando por meio de Estêvão que o autêntico culto está relacionado com o reconhecimento do legítimo guia e chefe de que Deus suscita para o seu povo ao longo das várias etapas da sua existência histórica. Frisa, porém, que a história de Israel é caracterizada pela recusa constante às pessoas carismáticas que Deus põe à frente do seu povo, sem entender

${ }^{19}$ PEÑA, G. A., História da Igreja, p. 51. 
o projeto do Altíssimo. Segue-se que, com facilidade, o culto divino fica deturpado e não corresponde mais ao plano de Deus. ${ }^{20}$

José e Moisés, na narrativa, emergem como aqueles guias desprezados. Para Lucas, a fidelidade ao enviado de Deus e o correto desempenho da tarefa cultual do povo da promessa são elementos afins. Neste sentido, o culto de Israel é idolátrico e, por isso rejeitado por Deus: "Homens de dura serviz, e de corações e ouvidos incircuncisos! Vós sempre resistis ao Espírito Santo. Como procederam vossos pais, assim procedeis vós também! A qual dos profetas não perseguiram vossos pais? Mataram os que prediziam a vinda do Justo..." (At 7,51-52). Para Lucas, o Templo, construído por Salomão, representa um falso entendimento do culto que se deve a Deus. Ele não é uma habitação adequada ao Altíssimo. ${ }^{21}$ Não há mais um único lugar de culto. O novo templo e o novo culto ocorrem com a união dos fiéis em torno do Cristo, o Messias enviado da parte de Deus, rejeitado pelos judeus. ${ }^{22}$ Até aquele momento o povo nutria simpatia pelos cristãos (At 2,47; 5,26). A partir do discurso de Estêvão, começam a se colocar ao lado dos chefes (At 6,12). O desfecho é dramático e envolto numa atmosfera de indignação, violência e visões celestiais. O martírio de Estêvão é acompanhado de imagens que aprovam seu discurso: "cheio do Espírito Santo, Estêvão fitou o céu e viu a glória de Deus e Jesus de pé à direita de Deus" (At 7,55).

Em síntese, Lucas evidencia que o culto e o Templo de Jerusalém são próprios de um determinado tempo histórico que chegou ao fim. Seus sacrifícios são ineficazes e plenamente dispensáveis. O novo templo e o novo culto se encerram em Cristo Jesus, o cordeiro verdadeiro que tira o pecado do mundo. Com a morte de Estêvão, inicia-se uma perseguição a Igreja de Jerusalém, onde "todos se dispersaram pelas regiões da Judeia e da Samaria, com exceção dos apóstolos" (At 8,1b). A negação do Templo e do seu culto leva a dispersão da Igreja. Concordo com Simon quando afirma que Estêvão compreendeu a mensagem de Jesus de forma mais completa e precisa que os primeiros discípulos, ainda muito ensimesmados no Messias judeu e não no Senhor de todos os povos. É certo, então, afirmar que os discípulos de

\footnotetext{
${ }^{20}$ CASAlEGNO, A., Ler os Atos dos Apóstolos, p. 168.

${ }^{21}$ CASALEGNO, A., Ler os Atos dos Apóstolos, p. 174-175.

22 "Mas vem a hora, e já chegou, em que os verdadeiros adoradores hão de adorar o Pai em espírito e verdade, e são esses adoradores que o Pai deseja. Deus é espírito, e os seus adoradores devem adorá-lo em espírito e verdade" (Jo 4,23-24).
} 
Estêvão, os helenistas, fossem os verdadeiros iniciadores da missão cristã fora de Jerusalém. Sua mensagem, ao questionar elementos importantes da Lei ritual e desligar o movimento cristão do culto de Jerusalém, foi o estopim para uma missão de caráter universal. Os cristãos oriundos do judaísmo helenista foram responsáveis de dar a direção da emancipação cristã. ${ }^{23}$

Os eventos que se seguem mostram a aplicação deste método. Assim, no capítulo 8, Lucas concentra-se em outro líder dos Sete: Filipe, que se dirige aos judeus heterodoxos e aos gentios. "Os que haviam dispersado iam por toda parte, anunciando a palavra (de Deus). Assim Filipe desceu à cidade da Samaria, pregando-lhes Cristo" (At 8,4-5). Sua atuação também é corada de aprovação divina: "a multidão estava atenta ao que Filipe lhe dizia, escutando-o unanimemente e presenciando os prodígios que fazia. Pois os espíritos imundos de muitos possessos saíam levantando grandes brados. Igualmente foram curados muitos paralíticos e coxos" (At 8,6-7). Os sinais, milagres, têm a função de provar seu valor, mostrando que age por meio do Espírito de Deus.

A missão de Filipe é colocada em paralelo com a dos apóstolos. Este se encontra com samaritanos e, depois, com Simão, o mago (At 8,5-11). O desfecho da pregação é o batismo (At 8,12-13). Os apóstolos, semelhantemente, encontram-se com os samaritanos (At 8,14-17) e, depois, com Simão, o mago (At 8,18-24). Os apóstolos ratificam a missão de Filipe ao orarem pela efusão do Espírito Santo sobre os samaritanos por ele batizados. Eles também passam, então, a ser semelhantemente responsáveis pela missão da Igreja. Contudo, será o encontro de Filipe com o eunuco (At 8,26-40) o ponto central de visibilidade deste novo modo de fazer discípulos, onde o batismo tem papel central, conforme as palavras do Senhor: "Ide, pois, e ensinai a todas as nações; batizai-as em nome do Pai, do Filho e do Espírito Santo" (Mt 28,19).

O termo "eunuco" tem muitas designações. Pode ser um homem de confiança das cortes estrangeiras, como o copeiro-mor e o padeiro-mor que, no Egito, atuavam nas dependências do Faraó (Gn 40,2). Também os oficiais do estado-maior ou os supervisores da corte de Nabucodonosor na Babilônia ( $\mathrm{Jr}$ 39,3.13; Dn 1,8-9.18; 2Rs 20,18). Assim também os altos funcionários no reino de Israel (1Rs 22,9; 2Rs 8,6; 9,23). ${ }^{24}$ Também indica pessoas emasculadas, responsáveis pelo harém de um rei. Esse alto funcionário da rainha da Etiópia,

\footnotetext{
${ }^{23}$ SIMON, M., St. Stephen and the Hellenists in the primitive Church, p. 110-112.

${ }^{24}$ GANCHO, C., Eunuco, p. 267-268.
} 
era um não-judeu que, no entanto, demonstra simpatia pelo judaísmo. Voltava de Jerusalém e lia o livro de Isaias (At 8,27.30). Trata-se do primeiro nãojudeu a abraçar a fé em Cristo. Lucas aponta, assim, para um novo momento do Evangelho. Depois da evangelização dos judeus ortodoxos de Jerusalém (At 2,41), dos judeus helenistas (At 6,1) e dos judeus heterodoxos da Samaria (At 8,12 ), os gentios emergem como objeto de evangelização. ${ }^{25}$

Os "dispersos", como são designados os Sete, e seu círculo, dirigem-se ainda para Azoto e Cesareia (At 8,26-40), mas, foi em Antioquia (At 11,1930) que a missão prosperou. Gentios foram aceitos na comunidade e, não demorou muito, tornou-se um importante centro missionário. As razões do sucesso podem ser identificadas. (I) A primeira é o conhecimento da língua e da cultura. ${ }^{26} \mathrm{~A}$ principal forma de comunicação no mundo antigo era a palavra oral. Sem dúvida, conhecer a língua e a cultura facilitou a elaboração de estratégias de atingimento e convencimento. Um dos Sete era, inclusive, de Antioquia: Nicolau. Este gentio havia se convertido inicialmente ao judaísmo (prosélito). Esta questão aponta para a segunda característica do sucesso naquela cidade: (II) um campo missionário propício. Em Antioquia havia muitos gentios simpatizantes do monoteísmo que se sentiam desconfortáveis por não serem plenamente aceitos no judaísmo. Formavam, assim, um público disposto a ouvir e aderir a mensagem cristã.

Os "tementes a Deus" eram pessoas admiradoras do monoteísmo judaico, mas que não se convertiam por causa da exigência da circuncisão. As sinagogas da diáspora, inclusive, sentiam orgulho desta clientela, pois, muitos eram oriundos de classes cultas e abastadas que ocupavam cargos de responsabilidade nas instituições da cidade. Apesar disso, não os admitiam como membros da comunidade, ou seja, como inseridos na categoria de "povo de Deus". Na prática estavam excluídos de eventos importantes como, por exemplo, da celebração da Páscoa. O círculo dos Sete se dirigiu às sinagogas de Antioquia não por buscar anunciar o Evangelho primeiro os judeus, mas, por entender que gentios tementes a Deus estavam mais propensos à conversão. De acordo com Atos 11,20, eles admitiam os gregos como membros plenos do povo de Deus mediante o batismo, conforme fez o diácono Filipe, com o servo de Candace (At 8,26-40). Não se pedia a circuncisão. Os seguidores de Jesus, em Antioquia, faziam legalmente parte da comunidade judaica. Habitavam os

${ }^{25}$ CASAlEgNO, A., Ler os Atos dos Apóstolos, p. 195.

${ }^{26}$ IRVIN, D. T.; SUNQUIST, S. W., História do movimento cristão mundial, p 53. 
mesmos quarteirões e se encontravam na mesma sinagoga. Com sua proposta sem circuncisão, apenas mediante o batismo, muitos tementes a Deus encontraram naquela mensagem a resposta aos seus anseios. Literalmente, os discípulos de Jesus ofereciam mais (plena participação) por menos (sem circuncisão). ${ }^{27}$

A cultura helenista continha fortes proibições quanto a marcar o corpo do homem. A circuncisão era um impedimento à conversão plena de gregos ao judaísmo, questão que os discípulos dos Sete não exigiam para que se tornassem cristãos. Por fim, (III) ir para Antioquia cumpria perfeitamente o programa universalista dos cristãos helenistas. A cidade tinha importância geográfica dentro do Império Romano. Capital da Síria, desde 64 a.C., tornou-se área favorável para o comércio por terra e mar. Era cosmopolita e multicultural. ${ }^{28}$ Situava-se na extremidade ocidental da rota da seda. A presença de cerâmica chinesa encontrada nas ruínas da cidade testemunha seu caráter internacional com ondas de imigrantes e comerciantes..$^{29}$ Assim, a escolha da cidade, com cerca de 500 mil habitantes, foi fundamental para os anseios daqueles que ali foram chamados a primeira vez de cristãos (At 11,26).

Os gentios passam a se tornar objeto da mensagem evangélica com a missão dos Sete e seus discípulos. Foi em Antioquia que o anúncio ganhou certa oficialidade. Lucas destaca que pregadores helenistas vindos de Chipre e Cirene se dirigiram aos gregos. A prosperidade da missão é acentuada: "a mão do Senhor estava com eles e grande foi o número dos que receberam a fé e se converteram ao Senhor" (At 11,21). O sucesso da missão chegou aos ouvidos da Igreja de Jerusalém que enviou Barnabé até Antioquia. Chegando lá se alegrou em ver os frutos da missão (At 11,22-23). A escolha de seu representante foi acertada. Barnabé pertencia à comunidade de Jerusalém (At 9,27), no entanto, era levita originário de Chipre e compatriota dos primeiros evangelizadores da cidade (At 4,36-37). Conhecia sua mentalidade e era um interlocutor capaz de estabelecer afinidades e proximidade. Lucas o apresenta como homem prudente: "de bem e cheio do Espírito Santo e de fé" (At 11, 24c). ${ }^{30}$ Um novo personagem entra em cena: Saulo de Tarso.

Barnabé manda chamar Saulo que estava em sua cidade natal, bastante próxima dali e convida-o a trabalhar na comunidade (At 11,25). A missão

\footnotetext{
${ }^{27}$ EBNER, M., Dos primórdios até a metade do século II, p. 19-20, 28.

${ }^{28}$ SELVATICI, M., Os judeus helenistas e a primeira expansão cristã, p. 79, 83.

${ }^{29}$ IRVIN, D. T.; SUNQUIST, S. W., História do movimento cristão mundial, p 37.

${ }^{30}$ CASAlEGNO, A., Ler os Atos dos Apóstolos, p. 249.
} 
em Antioquia dura um ano e parece não ter ocorrido nenhum problema de relacionamento. A nova organização a fez prosperar ainda mais em número de membros (At 11,26). Havia proximidade com a Igreja de Jerusalém. Em tempos de dificuldade da Igreja Mãe, foi a comunidade de Antioquia que organizou uma coleta a favor dos irmãos da Judeia (At 11,29-30).

Saulo contribuía na organização da comunidade ao mesmo tempo em que aprendia sobre o novo método missionário. Fala-se muito da primeira viagem missionária de Paulo, como se ele fosse o único responsável. Lucas menciona em primeiro lugar Barnabé e depois "Saulo" (At 13,2). Repare que o nome "Paulo" ainda não é citado. Inicialmente, Lucas se refere a Saulo e, apenas mais tarde, quando de fato assume papel de liderança, seu nome é trocado para Paulo (At 13,46.50; 14,20; 15,2.22.35-36). Na narrativa lucana, o apóstolo é efeito de uma tomada de consciência missionária. Seu ponto de partida é a comunidade de Antioquia, para onde retorna e sai em missão outras duas vezes. Lucas, mais uma vez, aponta que a missão universal do Evangelho corresponde aos planos de Deus e é a comunidade de Antioquia a responsável pelo envio de Barnabé e Saulo: "Enquanto celebravam o culto do Senhor, depois de terem jejuado, disse-lhes o Espírito Santo: 'separai-me Barnabé e Saulo para a obra a que os tenho destinado'. Então, jejuando e orando, impuseram-lhes as mãos e os despediram" (At 13,2-3). Barnabé e Saulo não impuseram a circuncisão aos novos convertidos, conforme a prática missionária dos Sete e de seus epígonos. A nova mentalidade será, apesar das intensas discussões e disputas (G1 2,11-14), a prática oficialmente aceita e aprovada pelo Concílio de Jerusalém (At 15). ${ }^{31}$

\section{A diaconia dos Sete como comunhão de mesa e missão eclesial}

A diaconia dos Sete e dos helenistas dispersos de Jerusalém abre caminho para uma nova práxis missionária. A diaconia aplicada por eles e por seus epígonos foi, progressivamente, se estabelecendo, de forma que o texto lucano apresenta uma tomada de consciência apostólica progressiva que foi se afirmando, aos poucos, como missão eclesial. Os cristãos helenistas prepararam o caminho da missão para além da Palestina. A comunidade de Jerusalém vai tomando contato com a aplicação de novo método em Samaria e, de modo especial, em Antioquia. Após uma primeira fase de estranhamento

${ }^{31}$ CASAlEGNO, A., Ler os Atos dos Apóstolos, p. 257. 
e adaptação a diaconia dos Sete é vivenciada como ação apostólica ratificada por Lucas nos atos de Pedro e de Paulo.

A narrativa lucana é pedagógica. Apresenta no capítulo 6 a emergência do novo círculo de líderes da igreja, cuja missão se destina aos judeus helenistas. Seu exercício missionário é semelhantemente inovador. A obra de Lucas, que se situa entre os anos 80 e 90, composta em Antioquia da Síria, parece afirmar o sucesso dessa mentalidade missionária, centro irradiador das missões de Paulo nas décadas de 40 e 50, mais aberta do que aquela da comunidade de Jerusalém. ${ }^{32}$ Os fatos se articulam ao sopro do Espírito que orienta a missão para fora da Palestina. Ou seja, sua narrativa histórica trama a missão a diversos acontecimentos que vão dando forma aos atos da primeira geração cristã.

Primeiramente, (I) a cultura helenística emerge como pré-disposição de abertura e envolvimento com outros povos e nações. (II) $\mathrm{O}$ crescimento da igreja e suas primeiras estratégias de organização (criação dos Sete helenistas) produzem efeitos inesperados e, a princípio, trágicos. Um dos líderes dos Sete, Estêvão, é martirizado não apenas por apresentar Jesus como a última palavra de Deus e termo da revelação bíblica, mas, também por afirmar a ineficácia do culto de Jerusalém. Esses dois fatores lançaram os Sete e seu círculo do ambiente helenístico hierosolimitano para o judeu heterodoxo e gentílico.

Em Lucas, a perseguição dos helenistas abre caminho para novos horizontes missionários. ${ }^{33} \mathrm{~A}$ diaconia dos Sete é colocada em paralelo com os Doze. Depois da Morte de Estêvão "os que se haviam dispersado iam por toda parte, anunciando a palavra de Deus. Assim Filipe desceu à cidade da Samaria, pregando-lhes Cristo" (At 8,4-5). Filipe prega, realiza prodígios e expulsa espíritos. O termo desta cena é o batismo dos Samaritanos (At 8,513). "Os apóstolos que se achavam em Jerusalém, tendo ouvido que a Samaria recebera a Palavra de Deus, enviaram-lhe Pedro e João" (At 8,14). A prontidão no envio parece dever-se a surpresa de judeus heterodoxos serem acolhidos na comunidade de fé. Os samaritanos eram considerados impuros por parte dos judeus ortodoxos de Jerusalém, por serem fruto de matrimônios mistos entre judeus e assírios (c. 721 a.C.). Lucas afirma que os habitantes da cidade ficaram impressionados pelo anúncio da salvação de Filipe, que superou os truques de Simão, o mago. Afirma, com isso, a superioridade do anúncio evangélico.

${ }^{32}$ LORASCHI, C., Os Doze e os Sete, p. 133-146.

${ }^{33}$ BOSSUYT, P.; RADERMAKERS, J., Lettura pastorale degli Atti degli Apostoli, p. 337. 
As práticas mágicas deviam ter grande influência sobre os samaritanos. No entanto, o próprio Simão rendeu-se ao cristianismo, mesmo que de maneira interessada. ${ }^{34}$ A presença dos Apóstolos vai afirmar a bem sucedida missão de Filipe. Eles oram sobre os batizados e os tornam participantes da missão da comunidade (At 8,14-17.25). Judeus marginalizados são, então, colocados na pauta dos destinatários do Evangelho.

Lucas segue com a missão de Filipe em Gaza, junto ao funcionário da rainha da Etiópia (At 8,26-40), o primeiro gentio alcançado pela mensagem evangélica. É verdade que Lucas, querendo ressaltar o papel do apóstolo Pedro, destaca que o primeiro incircunciso aceito na Igreja foi Cornélio (At 10,1-48). No entanto, a sequência dos fatos aponta o diácono Filipe como o primeiro a aceitar um gentio como membro do povo de Deus, fazendo uso do batismo, sem exigir a circuncisão (At 8,27-38). É Deus que move a missão até os gentios. $\mathrm{O}$ anjo do Senhor lhe aponta o caminho e o Espírito o orienta a aproximar-se do eunuco tendo por termo o batismo (At 8,26.29.38). A cena é bastante significativa. Assim como brota uma fonte vivificante no deserto, semelhantemente brota no meio da gentilidade os novos cristãos. Dalí, Filipe seguiu para Azoto e demais cidades até Cesareia, cenários gentílicos, outros "desertos" cuja esterilidade dará lugar a vida nova. É justamente no deserto que Saulo, perseguidor da Igreja, se encontra com o Senhor e recebe o batismo numa cidade de atuação dos Sete: Damasco (9,1-22).

Damasco, cidade helenística na província romana da Síria, possuía uma grande comunidade judaica, cuja vida girava em torno da sinagoga. ${ }^{35}$ Foi ali que Paulo tomou conhecimento do novo método missionário, livre da circuncisão (At 22,11-16). Convertido e batizado, abraçou totalmente o programa desse grupo: agia entre os judeus marginalizados, entre os gentios e não exigia a circuncisão, mas, o batismo. Pedro, por sua vez, segue um caminho mais longo de aceitação do novo método. Ele age na mesma região que o diácono Filipe (At 9,32-42), após a conversão do eunuco. Percorria as regiões da Judeia, Galiléia e Samaria (At 9,31), mostrando que também os Doze se lançaram na atividade missionária fora de Jerusalém, embora ainda em território judaico. Neste sentido, o encontro de Pedro com o gentio Cornélio (At 10,1-11,18), representa um avanço na missão junto aos gentios. Lucas destaca o evento narrando-o três vezes em Atos (10,1-48; 11,1-18; 15,7-

\footnotetext{
${ }^{34}$ FABRIS, R., Os Atos dos Apóstolos, p. 157-167; COMBLIM, J., Atos dos Apóstolos, p. 165-170; HAENCHWN, E., The Acts of the Apostles, p. 303.

${ }^{35}$ IRVIN, D. T.; SUNQUIST, S. W., História do movimento cristão mundial, p. 47.
} 
11). Historicamente, pode-se duvidar que Cornélio seja verdadeiramente o primeiro pagão a ser aceito na Igreja. Esse primado pertence ao eunuco que foi adorar em Jerusalém e no retorno à Etiópia se deixou batizar por Filipe. ${ }^{36} \mathrm{Em}$ linhas gerais, Lucas parece apresentar o movimento histórico de convergência da missão em direção ao mundo gentílico. Pedro e, com ele, a comunidade de cristãos palestinenses, tinham uma atitude negativa a respeito da admissão de não judeus na Igreja. O encontro com Cornélio, após as diversas notícias da atuação dos Sete, demonstra uma mudança de atitude por parte dos Doze:

Então, Pedro tomou a palavra e disse: "Em verdade, reconheço que Deus não faz distinção de pessoas, mas em toda nação lhe é agradável aquele que o temer e fizer o que é justo" (...) Estando Pedro ainda a falar, o Espírito Santo desceu sobre todos os que ouviam a santa palavra. Os fiéis da circuncisão, que tinham vindo com Pedro, profundamente se admiravam, vendo que o dom do Espírito Santo era derramado também sobre os pagãos; pois eles os ouviam falar em outras línguas e glorificar a Deus. Então, Pedro tomou a palavra: "Porventura pode-se negar a água do batismo a estes que receberam o Espírito Santo como nós?”. E mandou que fossem batizados em nome de Jesus Cristo (At 10,34-35.44-48a).

Não se trata de um simples encontro entre dois personagens, mas de duas comunidades (cristã de origem palestinense e incircuncisos helenistas). Dois grupos divididos por cultura e mentalidade que se encontram. O Espírito Santo, contudo, ratifica o caminho junto aos gentios com sinais e prodígios. Pedro, já vinha tomando consciência da missão: "Vós sabeis que é proibido a um judeu aproximar-se de um estrangeiro ou ir à sua casa. Todavia, Deus me mostrou que nenhum homem deve ser considerado profano ou impuro" (At 10,28). E ainda "Reconheço que Deus não faz distinção de pessoas" (At 10,34). Após o derramamento do Espírito sobre os incircuncisos, Pedro ordena o batismo sem a necessidade da circuncisão. Quem o realiza são os que o acompanhavam: judeus cristãos de origem palestinense. Na narrativa, Lucas enfatiza que o caminho em direção aos gentios é obra do Espírito Santo que guia a Igreja e convence quanto ao caminho a ser seguido. Esse processo é pedagógico, lento e envolto em crises e conflitos, como o que ocorreu em Antioquia (G1 2,11-14).

$\mathrm{Na}$ atividade dos cristãos em Antioquia (At 11,19-21), os gentios eram admitidos na comunidade e, portanto, na qualidade de Povo de Deus, apenas

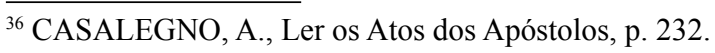


pelo batismo, sem a prática da circuncisão. ${ }^{37}$ Os "dispersos" de Jerusalém iniciaram na cidade o processo de distanciamento do judaísmo ao romper com a circuncisão como marca identitária. Esse modo de ser e de fazer, contudo, ainda era questionado e Pedro, que começara a aproximar-se dos gentios, teve que se explicar em Jerusalém: "Os apóstolos e os irmãos da Judeia ouviram dizer que também os pagãos haviam recebido a Palavra de Deus. E quando Pedro subiu a Jerusalém, os fiéis que eram da circuncisão repreenderam-no: 'Por que entraste em casa de incircuncisos e comeste com eles?'” (At 11,1). Pedro é reprovado não por causa do batismo dos incircuncisos (At 10,48), mas por ter praticado comunhão de mesa (At 11,1). Com as conversões em Antioquia um representante de Jerusalém assume a Igreja naquela cidade: Barnabé. Este, com o apoio de Saulo faz com que a missão prospere. O novo método missionário ganha impulso com Saulo que em Missão faz novos membros entre os gentios sem a necessidade da circuncisão que constantemente combatia em favor da graça de Deus (Rm 2,25; 3,1; G1 2,7; 6,15; Fl 3,2-3; Cl 2,11; Tt 1,10). Mais tarde, um desentendimento entre Paulo e Barnabé por causa de João Marcos, a quem Paulo recusa na segunda viagem missionária, parece ter por razão principal o problema do batismo aos incircuncisos.

O motivo do comportamento meio estranho do auxiliar [na primeira viagem] foi, provavelmente, a recusa da metodologia missionária dos seus companheiros que aceitavam na Igreja também os não circuncidados. É provável que sua atitude, fechada e conservadora, não mudou nem depois das decisões do Concílio [de Jerusalém]. Enquanto membro da comunidade de Jerusalém $(12,12)$ [para onde voltou ao abandonar a missão na Panfília $(13,13)]$, deve ter partilhado as opiniões de Tiago, cujos enviados em Antioquia, antes da emissão do decreto apostólico, fizeram com que Pedro e Barnabé deixassem de tomar suas refeições com os gentios. ${ }^{38}$

O Concílio de Jerusalém (At 15,1-33; Gl 2,1-10), ocorrido entre 48 e 49 d.C. é um evento de singular importância para o desenvolvimento da missão na Igreja antiga. Nele se debate a questão da imposição dos ritos da lei judaica aos gentios, de modo especial, a circuncisão, sinal de pertença ao povo da aliança. Dele participam as igrejas de Jerusalém e de Antioquia. Esta, em meados do século I goza de influência superior à Igreja Mãe, empobrecida

\footnotetext{
${ }^{37}$ SUFFERT, G., Tu és Pedro, p. 26-27.

${ }^{38}$ CASALEGNO, A., Ler os Atos dos Apóstolos, p. 297.
} 
economicamente (At 11,29) e composta por cristãos conservadores (At 21,20). A narrativa lucana passa pelos acontecimentos em Antioquia (At 13,1-3), depois, por Jerusalém (At 13,4-29) e termina com o que advém em Antioquia (At 13,30-35). A decisão tomada pela cúpula da Igreja é transmitida à comunidade antioquena (At 13,22-29). Após o encontro não foi imposta nenhuma prática judaica aos pagãos (At 15,10.19a.28; Gl 2,6). Na carta aos Gálatas, os notáveis de Jerusalém dão a mão direita a Paulo e a Barnabé em sinal de comunhão. ${ }^{39} \mathrm{Na}$ prática, o Concílio não apenas autoriza a atividade missionária que nasceu com os Sete, ali representada por Paulo, Barnabé e Tito, incircunciso e batizado (G1 2,1.3), como a toma por prática eclesial.

\section{Conclusão}

Não demorou muito, os cristãos deixaram as sinagogas e passaram a se reunir nas casas. Sua nova identidade estava circunscrita à mesa, onde judeus e gregos se reuniam numa família comum: a cristã. Os efeitos da nova mentalidade missionária para a Igreja podem, assim, ser brevemente resumidos. Primeiramente, foi o grupo dos Sete e seus epígonos que acelerou a transferência da tradição de Jesus do aramaico para o grego, articulando o pensamento cristão livre da pré-aculturação aramaica. A missão desenvolvida pelos helenistas tinha caráter urbano, fundamental para mover o cristianismo de seu contexto palestino para a cultura mais ampla do Império. Neste sentido, o anúncio do Evangelho deixou os traços meramente judaicos e delineou suas características próprias, condições fundamentais para suas pretensões universalistas. Sua missão foi a ponte entre Jesus e Paulo que aprimorou aquela teologia incipiente e the deu contornos eclesiais. Os Sete e seus discípulos foram os fundadores da missão cristã fora da palestina e de uma tradição teológica que articula o Evangelho ao mundo greco-romano. ${ }^{40}$

Inácio, que fora bispo da cidade de Antioquia, núcleo fundamental de atuação dos epígonos dos Sete, não por acaso afirma uma cristologia do ministério diaconal. Possivelmente foi o primeiro a produzir essa associação, afirmando serem "diáconos dos mistérios de Jesus Cristo", ${ }^{41}$ e também sinal sacramental de sua presença. Por isso, aconselha: "Acatem os diáconos, como

\footnotetext{
${ }^{39}$ CASALEGNO, A., Ler os Atos dos Apóstolos, p. 275-294.

${ }^{40}$ MARTIN, T.W., Hellenists, p. 136.

${ }^{41}$ INÁCIO DE ANTIOQUIA, Epístola aos Tralianos, 2,3.
} 
à lei de Deus" ${ }^{42}$ e respeitem "os diáconos como a Jesus Cristo". ${ }^{43}$ Certamente, seu discurso aponta para o reconhecimento do ministério diaconal como fundamental na organização da Igreja apostólica, mas, também condição sine qua non daquela primeira ação missionária. O Pastor de Hermas, no século seguinte, afirmará a condição do diaconado como fundamental da construção da Igreja: "Ouve agora o que se refere às pedras que entram na construção. As pedras quadradas e brancas, que se ajustam bem entre si, são os apóstolos, os bispos, os doutores e os diáconos. (...) desempenharam com pureza e santidade seu ministério (...) a serviço dos eleitos de Deus". ${ }^{44} \mathrm{O}$ serviço a mesa é, portanto, o lugar prioritário onde a Igreja estabelece sua relação consigo mesma, com o mundo e com Deus.

\section{Referências bibliográficas}

AQUINO, J. P. T. Atos 6.1-7: a gênese do ofício diaconal?. Fides Reformata, v. 15, n. 2, p. 9-20, jul./dez. 2010. Disponível em: <https://docs.google.com/ viewer?a=v\&pid=sites\&srcid=ZGVmYXVsdGRvbWFpbnxhdG9zNnR lb3xneDo2NzY4OTI0NmQyODM4NDJm>. Acesso em: 11 mai. 2017.

BARRETT, C. K. The International Critical Commentary. Edinburgh: T\&T Clark, 1994. v.1.

BENDINELLI, J. C. Diaconia da Palavra: o ministério e a missão do diácono permanente. São Paulo: Paulus, 2011.

BOSSUYT, P.; RADERMAKERS, J. Lettura pastorale degli Atti degli Apostoli: testimoni della Parola di grazia. Bologna: Edizioni Dehoniane Bologna, 1997.

CASAlegnO, A. Ler os Atos dos Apóstolos: estudo da teologia lucana da missão. São Paulo: Edições Loyola, 2005.

CATECISMO DA IGREJA CATÓlICA. Petrópolis: Vozes; São Paulo: Paulinas / Loyola, 1993.

COMBLIM, J. Atos dos Apóstolos. Petrópolis: Vozes, 1988. v.I.

EBNER, M. Dos primórdios até a metade do século II. In: KAUFMANN, T. et

${ }^{42}$ INÁCIO DE ANTIOQUIA, Epístola aos Esmirnenses, 8,1.

${ }^{43}$ INÁCIO DE ANTIOQUIA, Epístola aos Tralianos, 3,1.

${ }^{44}$ HERMAS, O Pastor. Cap. 13. 
al. História Ecumênica da Igreja. São Paulo: Edições Loyola / Paulus; São Leopoldo, RS: Editora Sinodal, 2012. v.1.

FABRIS, R. Os Atos dos Apóstolos. São Paulo: Loyola, 1991.

FELDMAN, L. Diaspora Synagogues: New Light from Inscriptions and Papyri. In: FELDMAN, L. Studies in Hellenistic Judaism. Leiden: Brill, 1996. p. 577-602.

GANCHO, C. Eunuco. In: MACHO, A. D.; BARTIMA, S. (Orgs.). Enciclopedia de la Biblia. Barcelona: Garriga, 1963. p. 267-268. v.II.

HAENCHWN, E. The Acts of the Apostles. Oxford: Blackwell, 1971.

HENGEL, M. The Origins of the Christian Mission. In: HENGEL, M. Between Jesus and Paul: Studies in the Earliest History of Christianity. London: SCM Press, 1983. p. 48-64.

INÁCIO DE ANTIOQUIA. Epístola aos Esmirnenses. Disponível em: $<$ http://www.atos6.teo.br/fontes-historicas/inacio-de-antioquia $>$. Acesso em: 04 mar. 2018.

INÁCIO DE ANTIOQUIA. Epístola aos Magnésios. Disponível em: <http:// www.atos6.teo.br/fontes-historicas/inacio-de-antioquia>. Acesso em: 04 mar. 2018.

INÁCIO DE ANTIOQUIA. Epístola aos Tralianos. Disponível em: <http:// www.atos6.teo.br/fontes-historicas/inacio-de-antioquia>. Acesso em: 04 mar. 2018.

IRVIN, D. T.; SUNQUIST, S. W. História do movimento cristão mundial: do cristianismo primitivo a 1453. São Paulo: Paulus, 2004. vol. I.

LORASCHI, C. Os Doze e os Sete: uma abordagem de At 6,1-7. Encontros Teológicos, v. 24, n. 54, p. 133-146, set./dez. 2009. Disponível em: $<$ https:// revista.facasc.edu.br/ret/article/view/296/284>. Acesso em: 27 fev. 2018.

MARTIN, T.W. Hellenists. In: FREEDMAN, D. N. Archor Bible Dictionary. New York: Doubleday, 1992. p. 135-136. v.3.

PADRES APOSTÓliCOS. Clemente Romano, Inácio de Antioquia, Policarpo de Esmirna, O pastor de Hermas, Carta de Barnabé, Pápias, Didáque. São Paulo: Paulus, 1995. (Patrística, 1).

PEÑA, G. A. História da Igreja: vinte séculos caminhando em comunidade. São Paulo: Editora Ave Maria, 2014. 
PIERRARD, P. História da Igreja. São Paulo: Paulus, 1982.

SELVATICI, M. Os judeus helenistas e a primeira expansão cristã: questões de narrativa, visibilidade histórica e etnicidade no Livro dos Atos dos Apóstolos. Campinas / SP, 2006. 247p. Tese. Instituto de Filosofia e Ciências Humanas, Universidade Estadual de Campinas.

SIMON, M. St. Stephen and the Hellenists in the primitive Church. London: Longmans, 1958.

SUFFERT, G. Tu és Pedro: santos, papas, profetas, mártires, guerreiros, bandidos. A história dos 20 séculos da Igreja fundada por Jesus Cristo. Rio de Janeiro: Objetiva, 2001.

Luciano Rocha Pinto Pós-doutor em Teologia pela Pontifícia Universidade Católica do Rio de Janeiro Doutor em História pela Universidade do Estado do Rio de Janeiro Rio de Janeiro / RJ - Brasil E-mail: luciannorocha@msn.com

Recebido em: 16/03/18

Aprovado em: 21/08/18 